680

http://dx.doi.org/10.1590/0100-2945-431/13

\title{
TOPWORKING OF' 'BENGAL' LYCHEE TREES IN THE STATE OF SÃO PAULO, BRAZIL ${ }^{1}$
}

\author{
MÁRCIO DE CARVALHO PIRES ${ }^{2}$, OSVALDO KIYOSHI YAMANISHI ${ }^{3}$, JOSÉ RICARDO PEIXOTO ${ }^{4}$
}

ABSTRACT - This study aimed to evaluate the performance of 'Feizixiao', 'Nuomici', 'Heiye', 'Kway May Pink' and 'Bengal' lychee cultivars topworked onto bearing 'Bengal' trees. The experiments were carried out in commercial orchard at Rio das Pedras Farm in Jundiaí, state of São Paulo. The experimental design consisted of randomized blocks in a subdivided parcel arrangement, in which the parcel consisted of five cultivars and the sub-parcel consisted of six evaluation periods. Five replicates of three plants per parcel and six grafts per plant, (with two grafts per main branch) were used. The trees were approximately 10 years old propagated by air layering and planted with $6 \times 4 \mathrm{~m}$ (416 plants/ha) spacing. The following characteristics were evaluated: success rate of the grafts, number of shoots, shoot length, number of nodes, number of leaves and chlorophyll content (SPAD). The control ('Bengal'/'Bengal') had the highest grafting success rate with $89.9 \%$. On the other hand, 'Heiye', 'Feizixião', 'Nuomici' and 'Kway May Pink' had, respectively, 60.6, 55.0, 52.6 and $47.0 \%$ grafting success rates. All of the shoot grafts had normal growth with no signs of incompatibility. Therefore, the cultivars studied are compatible with 'Bengal' and may be used on commercial orchards.

Index terms: Litchi chinensis Sonn., cultivars, propagation, and compatibility.

\section{SOBRE-ENXERTIA DE LICHIEIRAS CV. BENGAL NO ESTADO DE SÃO PAULO, BRASIL}

RESUMO-O presente trabalho teve como objetivo avaliar a performance das cultivares Feizixiao, Nuomici, Heiye, Kway May Pink e Bengal sobrenxertadas em lichieiras adultas e produtivas da cultivar Bengal. O experimento foi conduzido em pomar comercial da Fazenda Rio das Pedras, em Jundiaí - SP. O delineamento experimental adotado foi em blocos casualizados, em arranjo de parcelas subdivididas, sendo a parcela formada por 5 cultivares e a subparcela formada por 6 épocas de avaliação. Utilizou-se de 5 repetições de 3 plantas por parcela e 6 enxertos por planta (sendo 2 enxertos por pernada). As plantas enxertadas tinham cerca de 10 anos de idade provenientes de mudas obtidas por alporquia e plantadas em espaçamento $6 \times 4 \mathrm{~m}$ (416 plants/ha). Foram avaliadas as seguintes características: sucesso na enxertia dos enxertos, número de brotações, comprimento das brotações, número de entrenós ao longo de cada brotação, número de folhas e teor de clorofila (SPAD). A testemunha ('Bengal' / 'Bengal') apresentou os maiores índices de pegamento, com 89,9\%. Por outro lado, as cultivares Heiye, Feizixião, Nuomici e Kway May Pink apresentaram, respectivamente, taxa de pegamento de 60,6, 55,0, 52,6 e 47,0\%. Todos os enxertos pegos tiveram crescimento normal sem apresentar sinais de incompatibilidade. Portanto, as cultivares estudadas são compatíveis com a cv Bengal e podem ser usadas em pomares comerciais.

Termos para indexação: Litchi chinensis Sonn., cultivares, propagação, substituição de copa e compatibilidade.

\footnotetext{
'(Trabalho 431-13). Recebido em: 18-10-2013. Aceito para publicação em: 10-07-2014.

2Eng. Agr., D.Sc., Pós-Doutorando, FAV/UnB, Brasília-DF, mcpires@unb.br, bolsista CAPES.

${ }^{3}$ Eng. Agr., Ph.D., Professor, FAV/UnB, Brasília-DF, kiyoshi@unb.br.

${ }^{4}$ Eng. Agr., D.Sc., Professor, FAV/UnB, Brasília-DF, peixoto@unb.br, bolsista do CNPq.Campus Universitário Darcy Ribeiro -

Caixa Postal - 04508 - Asa Norte. Programa de Pós-Graduação em Agronomia - FAV/UnB.
} 


\section{INTRODUCTION}

A major problem for the cultivation of lychee in Brazil has been the lack of genetic variability, because 'Bengal' accounts for $99 \%$ of production. As a consequence there is a large supply of fresh fruit in a short period (December), resulting in lower prices for the producer (YAMANISHI et al., 2010).

From a commercial standpoint, lychee propagation is done vegetatively by the air layering technique (LYNCH, 2013).

However, lychee propagation by air layering presents the disadvantages of being a costly process and requiring skilled labor. Additionally, this method causes depletion of the mother plant wherein a large number of branches are removed (MARTINS et al., 2002). Because of this, more viable propagation processes, such as grafting (HARTMANN; KESTER, 2002), can provide a higher number of plants and be more economical. Furthermore, it is easier to conduct the production of seedlings in nurseries, compared to the layering in the trees (BASTOS et. al., 2006).

Besides, the quality of available nursery plants is essential for the introduction of new cultivars, in order to extend the harvest season and to sustain the development of the lychee industry in Brazil.

Topworking the established bearing 'Bengal' trees with earlier and later bearing cultivars can be an alternative to extend the harvest season much faster than establishing new plantings with new cultivars. Grafting is not used by Brazilian nurserymen due to its low success rate. According to (MENZEL; WAITE, 2005) the success rate of grafting on lychee is variable and often low, and this is due to incompatibilities between the scion and the rootstock, little cambium contact, grafting on physiologically incorrect timings and inadequate post-grafting management.

Topworking is used to change the cultivar of a tree by grafting over the trunk or large scaffolding branches. The trunk or branches of the tree are cut back to stumps over which scions of a new variety are grafted using crown or cleft grafts.

The present study aimed to evaluate the use of topworking on bearing lychee trees in order to reduce the time of insertion of new cultivars early-, mid- and late-season - that combined with the different climatic conditions would extend the harvest season from September to March, allowing exploitation windows in the international and local markets where there is little to no supply of fresh fruit. In addition, the commercial planting of 'Bengal' located in marginal areas where production is erratic or inexistent due to a lack of sufficient cold to trigger flower initiation could be solved by topworking cultivars with lower chilling requirements.

\section{MATERIAL AND METHODS}

The experiment was conducted at the Rio das Pedras, Jundiaí, State of São Paulo, with the coordinates $23^{\circ} 13^{\prime} 11.14$ " $\mathrm{S}, 46^{\circ} 00^{\prime} 30.30^{\prime \prime} \mathrm{W}$ and $680 \mathrm{~m}$ altitude. The climate is type "Tropical wet and dry climate" in transition to "Humid subtropical climate", with average annual minimum temperature of $11.6^{\circ} \mathrm{C}$, mean annual temperature of $16.3^{\circ} \mathrm{C}$, mean annual maximum temperature of $21.1^{\circ} \mathrm{C}$ and annual rainfall of 2,308.75 $\mathrm{mm}$.

The trees were approximately 10 years old clonally propagated by air layering. They were planted with $6 \times 4 \mathrm{~m}$ (416plants/ha) spacing and the grafting took place in January, 2009.

Scions used to topwork bearing 'Bengal' trees were as follows: 1 - 'Feizixiao', 2 - 'Nuomici', 3 - 'Heiye', 4 - 'Kwai May Pink' and 5 - 'Bengal'. The treatment 5 ('Bengal' / 'Bengal') was used as control trees.

Semi-woody scionwood with 10 to $15 \mathrm{~cm}$ long, 0.5 to $0.7 \mathrm{~mm}$ in diameter were taken from the middle part of well-ripened shoots of the previous year growth of bearing trees grown in Botucatu, State of São Paulo. As the scionwoods were collected they were stored in coolers lined with dampened paper and covered with crushed ice to keep them moist and cool during transportation to Jundiaí. Before grafting, the scionwoods were disinfected with quaternary ammonia solution $50 \%$ (Chemitec ${ }^{\circledR}$ ) and wrapped in parafilm containing at least 4 buds along their length. The trunk or main scaffold branches of the tree were cut back to stumps where scions of a new cultivar were grafted using crown or rind grafts. Shortly after grafting, the trunk or main scaffold branch with the scion grafts were covered with transparent plastic bag to form a moist chamber to enhance the grafting's chance of success, which were left until the bud burst and there was emergence of new sprouts from the grafts.

The orchard management was done as follows: usage of hand weeding under the trees' canopies, mowing and herbicide for weed control in between rows, application of agricultural lime, irrigation by microaspertion, phytosanitary control whenever necessary to keep the new shoots health and vigorous and two applications of NPK fertilizer per year, with the proportions: $160 \mathrm{~g}$ of $\mathrm{N}, 30 \mathrm{~g}$ of $\mathrm{P}_{2} \mathrm{O}_{5 \text { and } 120 \mathrm{~g}} \mathrm{~K}_{2} \mathrm{O}$ per plant, from prior to flowering up 
until post harvesting (from June to December) and fractioned into three applications.

The success rate of the grafts, number of shoots, shoot length, number of nodes, number of leaves and chlorophyll content (SPAD) were evaluated at $46,91,136,181,226$ and 271 days after grafting.

The experimental design consisted of randomized blocks in a subdivided parcel arrangement, where the parcel consisted of five cultivars and the sub-parcel consisted of six evaluation periods. Five replicates of three plants per parcel and six grafts per plant, (with two grafts per main branch) were used. Data collected were subjected to analysis of variance to assess the significance of treatment by $\mathrm{F}$ test, and levels of significance and means found were compared by Tukey test, at 5\% probability. The statistical analyses were performed using the software SISVAR developed by Ferreira (2008) at the Federal University of Lavras.

\section{RESULTS AND DISCUSSION}

As shown in Table 1, the 'Bengal' $x$ 'Bengal' combination, the control trees, had the highest success rate with $89.9 \%$ but did not differ significantly from the other grafted cultivars except cultivar 'Kwai May Pink'.

While studying topworking using different combinations of lychee cultivars, authors (HU et.al., 2010) noticed a vigorous growth of 'Nuomici' topworked into 'Baitangying', and also of cv. 'Feizixião' into 'Heiye'. They have attributed the success of these graftings to the high degree of compatibility between the cultivars (scion $\mathrm{x}$ rootstock compatibility).

The average number of shoots 271 days after grafting was higher in control trees with 3.20 shoots / graft, differing significantly from all grafted cultivars except 'Feizixiao' with 2.19 shoots. The shoot growth ceased at 181 and 226 days after grafting, the latter being the control trees (Table 2).

The average length of shoots of the grafts at 271 days after grafting was significantly higher in the control trees with $68,8 \mathrm{~cm}$ when compared with 'Kwai May Pink' and 'Heiye' grafts (Table 3).

There is fragmental information about scionrootstock compatibilities in lychee (HUANG and LI, 2007). It is generally believed that compatibility between scion and rootstock is closely related to genetic similarity of the two parts. According to the study by Liu and Mei (2005), genetic similarity to 'Guiwei' based on DNA finger printing followed the order of 'Nuomici' > 'Heiye' > 'Baitangying'>
'Baila'> 'Feizixiao', which is basically in agreement with their grafting compatibility.

In this study, there was significant difference in the length of shoots, which may indicate a greater degree of compatibility among cultivars 'Feizixiao', 'Nuomici', 'Heiye', 'Kway May Pink' and 'Bengal'.

Table 4 shows that the average number of internodes in the cultivar 'Bengal' was 12.3, a significantly higher average than cultivars 'Heiye' and 'Nuomici' with 7.73 and 7.86 , respectively. However, there was no difference with 'Feizixião' and 'Kwai May Pink'.

The highest mean number of leaves were obtained by plants topworked with cv 'Bengal', which was statistically higher than that of the cultivars 'Nuomici', 'Heiye', and 'Kway May Pink' except for the cultivar 'Feizixiao'. The highest number of leaves in plants topworked with cvs 'Feizixiao' and 'Bengal' may have occurred due to a greater degree of compatibility between the scion and the rootstock. (Table 5).

There were no significant differences in leaf greenness (SPAD value) among topworked cultivars with an average of 37.7 throughout the experiment (Table 6). Thus, the similar SPAD value among lychee cultivars topworked on 'Bengal' trees may indicate that they are compatible among then.

However, Fu et al. (2013) reported that significant difference in leaf greenness, determined by SPAD values, exists among lychee cultivars 'Heiye' (HY, SPAD 54-58), 'Feizixiao' (FZ, SPAD 49-52), 'Nuomici' (NM, SPAD 43-47) and 'Baila' (BL, SPAD 35-38). The difference does not seem to be related to leaf $\mathrm{N}$ concentration. The low SPAD values of the topworked cultivars compared with those reported by Fu et al. (2013) may be due to the hardiness of the measured leaves. 
TABLE 1 - Percentage of graft success in 'Bengal' trees topworked with the cultivars 'Feizixiao', 'Nuomici', 'Heiye', 'Kwai May Pink' and 'Bengal' (control) in Jundiaí-SP.

\begin{tabular}{cc}
\hline CULTIVARS & Graft success (\%) \\
\hline 'Feizixiao' / 'Bengal' & $55.00 \mathrm{AB}$ \\
'Nuomici' / 'Bengal' & $52.60 \mathrm{AB}$ \\
'Heiye'/ 'Bengal' & $60.60 \mathrm{AB}$ \\
'Kwai May Pink' / 'Bengal' & $47.00 \mathrm{~B}$ \\
Bengal / 'Bengal' & $89.90 \mathrm{~A}$ \\
\hline $\mathrm{CV}(\%)$ & 18.53 \\
\hline Means followed by same letter do not differ among themselves by Tukey test at 5\% probability.
\end{tabular}

TABLE 2 - Average number of shoots (NS), on topworked 'Bengal' trees with the cultivars 'Feizixiao', 'Nuomici', 'Heiye', 'Kwai May Pink' and 'Bengal' (control) in Jundiaí-SP .

\begin{tabular}{ccccccc}
\hline \multicolumn{7}{c}{ Days after grafting (DAG) } \\
\hline CUlTIVARS & $46 \mathrm{DAG}$ & $91 \mathrm{DAG}$ & $136 \mathrm{DAG}$ & $181 \mathrm{DAG}$ & $226 \mathrm{DAG}$ & $271 \mathrm{DAG}$ \\
\hline 'Feizixiao' & $1.13 \mathrm{~A} \mathrm{a}$ & $1.40 \mathrm{~A} \mathrm{a}$ & $1.59 \mathrm{~A} \mathrm{a}$ & $1.99 \mathrm{AB} \mathrm{a}$ & $1.99 \mathrm{AB} \mathrm{a}$ & $2.19 \mathrm{AB} \mathrm{a}$ \\
'Nuomici' & $1.73 \mathrm{~A} \mathrm{a}$ & $1.73 \mathrm{~A} \mathrm{a}$ & $1.73 \mathrm{~A} \mathrm{a}$ & $1.73 \mathrm{AB} \mathrm{a}$ & $1.73 \mathrm{AB} \mathrm{a}$ & $1.73 \mathrm{~B} \mathrm{a}$ \\
'Heiye' & $0.86 \mathrm{~A} \mathrm{a}$ & $0.86 \mathrm{~A} \mathrm{a}$ & $1.13 \mathrm{~A} \mathrm{a}$ & $1.33 \mathrm{~B} \mathrm{a}$ & $1.33 \mathrm{~B} \mathrm{a}$ & $1.33 \mathrm{~B} \mathrm{a}$ \\
'Kwai May Pink' & $1.00 \mathrm{~A} \mathrm{a}$ & $1.00 \mathrm{~A} \mathrm{a}$ & $1.13 \mathrm{~A} \mathrm{a}$ & $1.26 \mathrm{~B} \mathrm{a}$ & $1.26 \mathrm{~B} \mathrm{a}$ & $1.26 \mathrm{~B} \mathrm{a}$ \\
'Bengal' & $1.46 \mathrm{~A} \mathrm{c}$ & $1.80 \mathrm{~A} \mathrm{bc}$ & $2.46 \mathrm{~A} \mathrm{bc}$ & $2.93 \mathrm{~A} \mathrm{ab}$ & $3.20 \mathrm{~A} \mathrm{a}$ & $3.20 \mathrm{~A} \mathrm{a}$ \\
\hline CV1 (\%) & 30.23 & & & & \\
CV2 (\%) & 5.80 & & & & \\
\hline
\end{tabular}

Means followed by same uppercase (columns) and lowercase (lines), do not differentiate among themselves by Tukey test at $5 \%$ probability.

TABLE 3 - Average length of shoots (cm) on topworked 'Bengal' trees with the cultivars 'Feizixiao', 'Nuomici', 'Heiye', 'Kwai May Pink' and 'Bengal' (control) in Jundiaí -SP.

\begin{tabular}{ccccccc}
\hline \multicolumn{7}{c}{ Days after grafting (DAG) } \\
\hline CULTIVARS & $46 \mathrm{DAG}$ & $91 \mathrm{DAG}$ & $136 \mathrm{DAG}$ & $181 \mathrm{DAG}$ & $226 \mathrm{DAG}$ & $271 \mathrm{DAG}$ \\
\hline 'Feizixiao' & $5.65 \mathrm{~A} \mathrm{e}$ & $11.62 \mathrm{~A} \mathrm{de}$ & $19.76 \mathrm{Acd}$ & $28.51 \mathrm{~A} \mathrm{bc}$ & $40.12 \mathrm{~A} \mathrm{ab}$ & $52.76 \mathrm{AB} \mathrm{a}$ \\
'Nuomici' & $4.16 \mathrm{Ad}$ & $10.24 \mathrm{~A} \mathrm{~cd}$ & $18.04 \mathrm{~A} \mathrm{bc}$ & $24.70 \mathrm{~A} \mathrm{bc}$ & $35.38 \mathrm{~A} \mathrm{ab}$ & $48.65 \mathrm{AB} \mathrm{a}$ \\
'Heiye' & $5.46 \mathrm{Ad}$ & $9.59 \mathrm{~A} \mathrm{~cd}$ & $20.49 \mathrm{~A} \mathrm{bc}$ & $29.12 \mathrm{~A} \mathrm{ab}$ & $36.03 \mathrm{~A} \mathrm{ab}$ & $44.72 \mathrm{~B} \mathrm{a}$ \\
'Kwai May Pink' & $4.73 \mathrm{Ad}$ & $10.43 \mathrm{~A} \mathrm{~cd}$ & $18.93 \mathrm{~A} \mathrm{bc}$ & $26.56 \mathrm{~A} \mathrm{ab}$ & $36.17 \mathrm{~A} \mathrm{ab}$ & $45.60 \mathrm{~B} \mathrm{a}$ \\
'Bengal' & $6.06 \mathrm{Ad}$ & $18.66 \mathrm{Ac}$ & $31.10 \mathrm{~A} \mathrm{bc}$ & $41.78 \mathrm{~A} \mathrm{~b}$ & $52.46 \mathrm{~A} \mathrm{ab}$ & $68.79 \mathrm{~A} \mathrm{a}$ \\
\hline CV1 $(\%)$ & 39.43 & & & & \\
CV2 $(\%)$ & 6.86 & & & & \\
\hline
\end{tabular}

Means followed by same uppercase (columns) and lowercase (lines), do not differentiate among themselves by Tukey test at $5 \%$ probability. 
TABLE 4 - Average number of nodes on topworked 'Bengal' trees with the cultivars 'Feizixiao', 'Nuomici', 'Heiye', 'Kwai May Pink' and 'Bengal' (control) in Jundiaí -SP.

\begin{tabular}{ccccccc}
\hline \multicolumn{7}{c}{ Days after grafting (DAG) } \\
\hline CUlTIVARS & $46 \mathrm{DAG}$ & $91 \mathrm{DAG}$ & $136 \mathrm{DAG}$ & $181 \mathrm{DAG}$ & $226 \mathrm{DAG}$ & $271 \mathrm{DAG}$ \\
\hline 'Feizixiao' & $0.86 \mathrm{Ac}$ & $2.33 \mathrm{Ac}$ & $3.20 \mathrm{~A} \mathrm{bc}$ & $5.73 \mathrm{AB} \mathrm{ab}$ & $7.13 \mathrm{AB} \mathrm{a}$ & $9.66 \mathrm{AB} \mathrm{a}$ \\
'Nuomici' & $0.73 \mathrm{Ad}$ & $1.39 \mathrm{~A} \mathrm{~cd}$ & $2.13 \mathrm{~A} \mathrm{~cd}$ & $3.79 \mathrm{~B} \mathrm{bc}$ & $5.60 \mathrm{~B} \mathrm{ab}$ & $7.86 \mathrm{~B} \mathrm{a}$ \\
'Heiye' & $0.73 \mathrm{Ac}$ & $1.86 \mathrm{Ac}$ & $2.60 \mathrm{~A} \mathrm{bc}$ & $4.80 \mathrm{AB} \mathrm{ab}$ & $6.33 \mathrm{AB} \mathrm{a}$ & $7.73 \mathrm{~B} \mathrm{a}$ \\
'Kwai May Pink' & $0.80 \mathrm{Ac}$ & $1.53 \mathrm{Ac}$ & $2.33 \mathrm{~A} \mathrm{bc}$ & $4.73 \mathrm{AB} \mathrm{ab}$ & $6.26 \mathrm{AB} \mathrm{a}$ & $8.33 \mathrm{AB} \mathrm{a}$ \\
'Bengal' & $1.00 \mathrm{~A} \mathrm{e}$ & $3.33 \mathrm{~A} \mathrm{de}$ & $4.33 \mathrm{~A} \mathrm{~cd}$ & $7.40 \mathrm{~A} \mathrm{bc}$ & $9.86 \mathrm{~A} \mathrm{ab}$ & $12.33 \mathrm{~A} \mathrm{a}$ \\
\hline CV1 $(\%)$ & 34.52 & & & & \\
CV2 $(\%)$ & 7,1 &
\end{tabular}

Means followed by same uppercase (columns) and lowercase (lines), do not differentiate among themselves by Tukey test at $5 \%$ probability.

TABLE 5 - Average number of leaves on topworked 'Bengal' trees with the cultivars 'Feizixiao', 'Nuomici', 'Heiye', 'Kwai May Pink' and 'Bengal' (control) in Jundiaí -SP.

\begin{tabular}{ccccccc}
\hline \multicolumn{7}{c}{ Days after grafting (DAG) } \\
\hline CULTIVARS & $46 \mathrm{DAG}$ & $91 \mathrm{DAG}$ & $136 \mathrm{DAG}$ & $181 \mathrm{DAG}$ & $226 \mathrm{DAG}$ & $271 \mathrm{DAG}$ \\
\hline 'Feizixiao' & $0.60 \mathrm{~A} \mathrm{e}$ & $3.33 \mathrm{~A} \mathrm{de}$ & $9.06 \mathrm{~A} \mathrm{~d}$ & $21.53 \mathrm{~A} \mathrm{c}$ & $40.00 \mathrm{AB} \mathrm{b}$ & $62.33 \mathrm{AB} \mathrm{a}$ \\
'Nuomici' & $0.20 \mathrm{~A} \mathrm{~d}$ & $1.86 \mathrm{~A} \mathrm{~cd}$ & $6.40 \mathrm{~A} \mathrm{bc}$ & $15.06 \mathrm{~A} \mathrm{~b}$ & $31.66 \mathrm{~B} \mathrm{a}$ & $50.86 \mathrm{~B} \mathrm{a}$ \\
'Heiye' & $0.30 \mathrm{~A} \mathrm{~d}$ & $2.60 \mathrm{~A} \mathrm{~cd}$ & $7.80 \mathrm{~A} \mathrm{bc}$ & $18.06 \mathrm{~A} \mathrm{~b}$ & $35.33 \mathrm{~B} \mathrm{a}$ & $50.06 \mathrm{~B} \mathrm{a}$ \\
'Kwai May Pink' & $0.26 \mathrm{Ad}$ & $1.93 \mathrm{~A} \mathrm{~cd}$ & $7.00 \mathrm{~A} \mathrm{bc}$ & $18.20 \mathrm{~A} \mathrm{~b}$ & $35.33 \mathrm{~B} \mathrm{a}$ & $54.00 \mathrm{~B} \mathrm{a}$ \\
'Bengal' & $0.33 \mathrm{Ad}$ & $4.60 \mathrm{~A} \mathrm{~cd}$ & $12.06 \mathrm{Ac}$ & $27.20 \mathrm{~A} \mathrm{~b}$ & $54.32 \mathrm{~A} \mathrm{a}$ & $79.00 \mathrm{~A} \mathrm{a}$ \\
\hline CV1 (\%) & 40.63 & & & & \\
CV2 (\%) & 11.55 & & & & \\
\hline
\end{tabular}

Means followed by same uppercase (columns) and lowercase (lines), do not differentiate among themselves by Tukey test at $5 \%$ probability.

TABLE 6 - Average content of chlorophyll in the leaves on topworked 'Bengal' trees with the cultivars 'Feizixiao', 'Nuomici', 'Heiye', 'Kwai May Pink' and 'Bengal' (control) in Jundiaí -SP.

\begin{tabular}{ccccccc}
\hline \multicolumn{7}{c}{ Days after grafting (DAG) } \\
\hline CULTIVARS & $46 \mathrm{DAG}$ & $91 \mathrm{DAG}$ & $136 \mathrm{DAG}$ & $181 \mathrm{DAG}$ & $226 \mathrm{DAG}$ & $271 \mathrm{DAG}$ \\
\hline 'Feizixiao' & $0.01 \mathrm{~A} \mathrm{~d}$ & $6.47 \mathrm{Ac}$ & $16.90 \mathrm{~A} \mathrm{bc}$ & $17.38 \mathrm{~A} \mathrm{~b}$ & $28.47 \mathrm{~A} \mathrm{ab}$ & $43.17 \mathrm{~A} \mathrm{a}$ \\
'Nuomici' & $0.01 \mathrm{~A} \mathrm{~d}$ & $4.86 \mathrm{~A} \mathrm{~cd}$ & $11.22 \mathrm{Ac}$ & $13.41 \mathrm{~A} \mathrm{bc}$ & $23.76 \mathrm{~A} \mathrm{ab}$ & $29.21 \mathrm{~A} \mathrm{a}$ \\
'Heiye' & $0.01 \mathrm{~A} \mathrm{e}$ & $7.05 \mathrm{Ad}$ & $12.42 \mathrm{~A} \mathrm{~cd}$ & $17.49 \mathrm{~A} \mathrm{bc}$ & $28.44 \mathrm{~A} \mathrm{ab}$ & $43.12 \mathrm{~A} \mathrm{a}$ \\
'Kwai May Pink' & $0.01 \mathrm{~A} \mathrm{e}$ & $3.79 \mathrm{~A} \mathrm{de}$ & $8.84 \mathrm{~A} \mathrm{~cd}$ & $15.28 \mathrm{~A} \mathrm{bc}$ & $26.42 \mathrm{~A} \mathrm{ab}$ & $30.41 \mathrm{~A} \mathrm{a}$ \\
'Bengal' & $0.01 \mathrm{~A} \mathrm{e}$ & $6.68 \mathrm{Ad}$ & $14.35 \mathrm{Acd}$ & $20.07 \mathrm{~A} \mathrm{bc}$ & $29.04 \mathrm{~A} \mathrm{ab}$ & $39.30 \mathrm{~A} \mathrm{a}$ \\
\hline CV1 (\%) & 40.64 & & & & & \\
CV2 (\%) & 12.02 & & & & \\
\hline
\end{tabular}

Means followed by same uppercase (columns) and lowercase (lines), do not differentiate among themselves by Tukey test at 5\% probability. 


\section{CONCLUSIONS}

Topworking of bearing 'Bengal' trees with 10 years-old was shown to be viable in commercial orchards.

The combination of 'Bengal' $x$ 'Bengal' had the highest grafting success rate, which may due to a greater affinity between the scion and the rootstock.

The combinations 'Bengal' $x$ 'Bengal' and 'Feizixiao' $\mathrm{x}$ 'Bengal' have the best results considering the average number of shoots, average length of shoots, average number of nodes and leaves.

The amount of chlorophyll was similar for all topworked cultivars, thus indicating the feasibility and vigor of these graftings.

\section{REFERENCES}

BASTOS, D. C.; PIO, R.; FILHO, J. A. S.; ALMEIDA, L. F. P.; ENTELMANN, F. A.; ALVES, A. S. R. Tipo de estaca e concentração de ácido indolbutírico na propagação da lichieira. Ciência Agrotecnica, Lavras, v. 30, n. 1, p. 97-102, jan./ fev., 2006.

FERREIRA, D. F. SISVAR: um programa para análises e ensino de estatística. Revista Symposium, Lavras, v. 6, p. 36-41, 2008.

FU, X.; ZHOU, L.; HUANG, J.; MO, W.; ZHANG, J.; LI, J.; WANG, H.; HUANG, X. Relating photosynthetic performance to leaf greenness in litchi: A comparison among genotypes. Scientia Horticulturae, Amsterdam, v. 152, p. 16-25, 2013.
HARTMANN, H. T.; KESTER, D. E.; DAVIES JUNIOR, F. T.; GENEVE, R. L. Plant propagation: principles and practices. $7^{\text {th }}$ ed. New Jersey: Prentice Hall, 2002. 880 p.

HU, G.B.; CHEN, H.B.; HUANG, X.M.; BU, J.H. Shoot growth from scions top-grafted on different litchi cultivars. Acta Horticulturae, The Hague, v. 863, p. 449-452, 2010.

HUANG, D.Y.; LI, E.P. Key techniques in litchi top-grafting. South China Fruits, v.36, n.3, p. 45-46, 2007.

LIU, C.; MEI, M. Classification of lychee cultivars with RAPD analysis. Acta Horticulturae, The Hague, v. 665, p. 149-160, 2005.

LYNCH, S. John. Current methods of vegetative propagation of avocado, mango, lychee and guava in Florida. Ceiba, Tegucigalpa, v. 4, n. 6, p. 315336, 2013.

MARTINS A. B. G.; RAMOS, R. A.; SILVA, EA. V. C. Tipo de Porta-enxerto e Anelamento de Ramos no Pegamento da Enxertia em Lichieira (Litchi chinensis Sonn.). Revista Brasileira de Fruticultura, Jaboticabal, v. 24, n. 1, p. 175-177, abril 2002.

MENZEL, C. M.; WAITE, G. K. Litchi and longan: botany, cultivation and uses. Queensland: CABI Publishing, 2005. 305 p.

YAMANISHI, O. K.; PIRES, M. C.; ALMEIDA, L. F. P. The Brazilian lychee industry - present and future. Acta Horticulturae, The Hague, v. 863, p. 59-65, 2010. 